\title{
ERRATA, VOLUME 61
}

David Nelson, Recursive functions and intuitionistic number theory.

p. 332. Display (i) should read

(i) $\quad p(a, a, d)=h^{\prime}\left((d)_{t_{1^{\prime}}(a, a)}, \cdots,(d)_{t^{\prime}(a, a)}, a, a\right)$.

p. 343 , line 16. Read "l" for " $l$ ". 